Виталий Викторович Гончаров*

Гагик Оганесович Казахеиян ${ }^{* *}$

\title{
Особенности системы источников конституционного права \\ в Исламской Республике Иран
}

\section{Features of the system of sources of constitutional law in the Islamic Republic of Iran}

Ключевые слова: источник права, исламское право, правовая доктрина, система права

Keywords: source of law, Islamic law, legal doctrine, system of law

\begin{abstract}
Аннотация: Настоящая статья посвящена рассмотрению некоторых элементов исходной системь иранского законодательства. Правовая система Исламской Республики Иран имеет ряд особых элементов, которых нет ни в одной другой стране современного мира. Эти особенности связаны с тем, что государственное устройство Ирана представляет собой систему гражданско-религиозных властей, играющих первостепенную роль.
\end{abstract}

Abstract: The work is devoted to the consideration of some of the elements of the original system of Iranian legislation. The legal system of the Islamic Republic of Iran has a number of special elements that are not found in any other country in the modern world. These features are due to the fact that the state structure of Iran is a system of civil and religious authorities that play a primary role.

* ORCID ID: https://orcid.org/0000-0003-3029-4727; кандидат юридических наук, доцент кафедры государственного и международного права, ФГБОУ ВО «Кубанский государственный аграрный университет им. И.Т. Трубилина», Российская Федерация. Email: niipgergo2009@mail.ru

** ORCID ID: https://orcid.org/0000-0003-0865-8483; сотрудник кафедры государственного и международного права, ФГБОУ ВО «Кубанский государственный аграрный университет им. И.Т. Трубилина», Российская Федерация. Email: mail@kubsau.ru 
Система источников конституционного права в Исламской Республике Иран отличается самобытностью в силу исторических особенностей возникновения и развития данного государства по культурной революции 1979 года.

Так, большой интерес представляют значение и место решений Высшего совета культурной революции в правовой системе страны. Этот статус был установлен приказом имама Хомейни в 1979 году и назывался «Штаб культурной революции». Верховный лидер объявил: «Давно имеется потребность в свершении культурной революции. Это является богоугодным исламским делом и желанием всей нации. До сих пор не предприняты необходимые шаги, а нация, и в особенности студенты, ждут их...»1․ Позже, в 1984 году, по предложению президента Ирана, Лидер подтвердил этот статус как «Высший совет культурной революции».

Позиция Совета в правовой системе республики остается спорной среди иранских законодателей и экспертов. Эти отличия заключаются в том, что, во-первых, создание соответствующих органов деятельности не предусмотрена Конституцией; во-вторых, она утверждена приказом Верховного лидера. Дело в том, что согласно иранской конституции, у лидера есть четкий мандат по статье 110. Это не предполагает создания какого-либо органа самостоятельно.

Однако, Высший совет культурной революции, Корпус стражей Исламской революции и некоторые другие образования являются примером обратного. Кроме того, Совет по охране Конституции - орган, являющийся официальным толкователем основного закона Ирана, при разъяснении положений статьи 110 указал, что «Верховный руководитель не может исполнять полномочия, не предусмотренные настоящей статьей».

Однако, временный лидер Ирана имеет законное право создавать новые органы, хотя это не входит в его полномочия. Эта ситуация основывается на том, что пункт 8 статьи 110 Конституции закрепляет среди полномочий высшего должностного лица Ирана преодолевать проблемы государства, которые не могут быть решены обычным путем, с помощью Ассамблеи по определению государственной целесообразности. В данном случае выражение «обычным путем» означает «посредством действий органов государственной власти». Другими словами, если возникает ситуация, когда высокопоставленные чиновники не могут исключить исключительную проблему, он имеет право принять экстренные меры. Эти средства, в свою очередь, могут выходить за рамки официальных полномочий. Поэтому создание Совета Культурной революции было осуществлением «экстренных мер». По словам

1 Комментарий Конституции Исламской Республики Иран, с. 80, http://www.shora-gc.ir (15.10.2020). 
Хомейни, западный образ жизни, насаждаемый в Иране, не контролируется никаким другим способом.

В соответствии с постановлением самого Совета «О статусе, целях и задачах Высшего совета культурной революции» ${ }^{2}$, этот орган является органом высокого уровня, который разрабатывает ряд политических линий, принимает решения, реализует руководство, культуру и т.д. Подчеркивается, что решения Совета имеют юридическую силу. Этот нормативный правовой акт показывает, что основной целью этого органа является реформирование и улучшение культуры и связанных с ней организаций в целом, обеспечение независимости государства и укрепление благочестивой исламской культуры на пути к созиданию.

Положение совета в иерархии иранских законодательных источников является значительным. В конституции Ирана говорится, что законодательная власть представлена только Меджлисом исламского совета. Из этого положения возникает ряд вопросов. Может ли решение совета отменить закон Меджлиса? Нужно ли заранее иметь закон о решении Верховного Совета по регулированию общественных отношений? Иранские юристы так описывают ситуацию: «Постановления совета имеют «юридическую силу» ${ }^{3}$. Это означает, что с юридической точки зрения они не являются «законом». Именно они ниже, чем законы, принятые Собранием в иерархии нормативных правовых актов, и со всеми их последующими правовыми последствиями ${ }^{4}$.

Это объяснение, кажется оправданным по нескольким причинам. Во-первых, иранский парламент избирается народом, людьми, имеющими право издавать законы. Члены Верховного Совета назначаются Верховным лидером, который поручает их составить обязательные документы. Но независимо от своего положения, лидер не мог быть важнее всего иранского народа. Во-вторых, принятие законов Меджлиса состоит из нескольких этапов. Сначала обсуждение в парламенте, затем двойное одобрение Совета по защите Конституции республики, при необходимости Собрание принимает решение о принятии закона, для определения государственной цели. Решения Высшего совета культурной революции принимаются большинством присутствующих на заседании этого органа и могут иметь не менее 12 положи-

2 Постановление Высшего совета культурной революции «О внутреннем регламенте деятельности Высшего совета культурной революции», http://www.shora-gc.ir (15.10.2020).

3 Комментарий Конституции Исламской Республики Иран, с. 80, http://www.shora-gc.ir (15.10.2020).

4 А. Маини, Статус Высшего совета культурной революичи в правовой системе Ирана, http://www.hawzah.net/fa/Article/View (15.10.2020). 
тельных голосов ${ }^{5}$. Исходя из этого, можно сказать, что решения Ассамблеи находятся под более строгим контролем и, соответственно, имеют большее значение. И в-третьих, Совет принимает решения только в строго определенных рамках в области культуры, в свою очередь, Ассамблея имеет право рассматривать любой вопрос.При этом, в соответствии со статьей 9, постановления о статусе, целях и задачах Высшего совета культурной революции решения этого органа утверждаются Верховным лидером. После принятия документально оформленное решение направляется руководителям ветвей государственной власти в компетентные органы для их исполнения. Юристы описывают процесс следующим образом: если решение государственного органа одобрено главой Ирана, значит, оно имеет силу его указа. В свою очередь, приказы Верховного лидера выше в иерархии источников права, чем парламентские законы. Таким образом, решения Высшего совета культурной революции имеют большую юридическую силу, чем законы Меджлиса.

Что касается юридических документов лидера Исламской Республики Иран, следует отметить несколько особых моментов. Согласно содержанию статьи 109 Конституции Республики Иран, одним из требований, предъявляемые лидеру, является наличие научных полномочий для издания фетв по различным вопросам исламского права. Фетва - это мнение влиятельного религиозного деятеля, имеющего право толковать исламские законы. Чем выше духовный ранг человека, тем более влиятельным он будет для мусульман. Высшее положение в этой иерархии занимает верховный лидер Ирана (его называют «образец для подражания»), поэтому его взгляды имеют решающее значение для большого числа мусульман (в основном иранских граждан). Фетвы часто звучат во время устных проповедей или выступлений, но могут быть в письменной форме или в электронном виде через сеть Интернет. Необходимо различать фетвы и приказы Верховного лидера. Фетвы религиозны и должны выполняться, потому что лидер может более точно интерпретировать постулаты божественной природы, исходя из своего положения и опыта. Фетвы основаны на понимании религиозных норм и опоре на них.

Лидер занимает высшее положение в иранском государственном аппарате. Этот вывод можно резюмировать из содержания статьи 5 Конституции Исламской Республики Иран «...управление делами правоверных и имамат в исламской умме возлагается на справедливого и набожного, обладающего широким кругозором, смелого и имеющего организаторские способности факиха» и статье 57: «...управление Исламской Республики Иран осущест-

5 Постановление Высшего совета культурной революции «О внутреннем регламенте деятельности Высшего совета культурной революции», http://www.shora-gc.ir (15.10.2020). 
вляется законодательной, исполнительной и судебной властями, которые функционируют под контролем абсолютного правления имама».

Следует отметить, что в предыдущей редакции Конституции Исламской Республики Иран статья 57 не содержала слова «абсолютная».

Например, можно сослаться на знаменитую фетву аятоллы Хомейни против автора «Сатанинских стихов», написанных Салманом Рушди: «Довожу до сведения всех мусульман мира, что автор книги «Сатанинские стихи», которая направлена против ислама, Пророка и Корана, а также издатели, знавшие ее содержание, приговариваются к смерти. Хочу, чтобы любой мусульманин, обнаруживший этих людей, незамедлительно убил бы их, чтобы никто больше не отважился осквернить то, что свято для мусульман. Те, кто погибнут на этом пути, будут шахидами. Если кому-то станет известно местонахождение указанных лиц, но он не сможет собственными силами убить их, ему нужно прибегнуть к помощи других правоверных, чтобы свершить необходимое» ${ }^{6}$. Эта фетва носит уголовный характер. Аятолла Хомейни, первый верховный лидер Ирана, основываясь на субъективном восприятии наступления на ислам, пришел к выводу, что работа писателя Салмана Рушди неприемлема. Согласно иранским законам, лидер не имеет право изгнать кого угодно. Но в своей роли высокопоставленного духовного лица он мог принимать такие решения. На основании вышеизложенного можно сделать вывод, что указы и фетвы Верховного лидера Ирана занимают высшие места в иерархии юридических ресурсов этой страны.

Следующим источником права в Иране, после вышеизложенного является решение Общей коллегии Верховного суда. Данный вывод можно сделать на основе положений статьи 270 Закона «О судопроизводстве в общих и революционных судах» ${ }^{7}$. Если Комиссия Высшего суда или другие суды низшей инстанции выносят такое решение на основании их понимания закона, председатель Верховного суда или Генеральный прокурор после получения информации должны потребовать единогласного пересмотра позиций. Общая коллегия состоит из главы Верховного суда или его заместителя, при присутствии генерального прокурора или его представителя, а также по меньше мере трех четвертей от общего количества глав и советников коллегий Верховного суда. Решение, принятое большинством на основе религиозных норм, остается в силе. Однако это не относится к окончательным решениям нижестоящих судов, но является обязательным для других сенатов Верховного суда в таких делах в будущем.

6 Фетва имама Рухолла Хомейни в отношении Салмана Рушди, http://www.shora-gc.ir (15.10.2020).

7 Закон Исламской Республики Иран «О судопроизводстве в общих и революционных судах», http://www.shora-gc.ir (15.10.2020). 
Следует отметить, что решения Генерального совета Верховного суда недействительны только на основании закона. Любой судья палат Верховного суда или нижестоящих судов может по любой причине получить заключение Генерального комитета Верховного суда при содействии Председателя Верховного суда или Генерального прокурора.

Обычай также является источником закона в Иране. Его можно назвать таковым в рамках того, что он дополняет положения шариата. Роль обычаев важна в области гражданского права, особенно в области частного договорного права. Совершенно не используется в уголовном судопроизводстве. Обычай является источником права, когда его использование подразумевается законодателями или когда есть прямая ссылка на него. Первое означает, что в тексте закона имеются понятия и выражения, для уяснения смысла которых необходимо обратиться к обычаю (например, «справедливая цена»), хотя в самом законе нет рекомендации обращаться к обычаю. Второе означает, что в самом тексте закона имеется ссылка на обычай. В качестве примера можно привести положения статьи 54 ГК Ирана: «Иные обстоятельства, позволяющие использовать имущество, не принадлежащее субъекту, определяются собственником или на основании обычая» ${ }^{8}$.

Следует отметить, что согласно статье 13 Конституции зороастрийцы, иудеи и христиане, проживающие в стране, признаются только религиозными меньшинствами; они имеют право исповедовать свою религию и решать проблемы в соответствии с принципами своих убеждений.

Отсюда следует, что источником права в Иране являются не только нормы ислама в смысле официальной религии страны, Джафар, но в некоторых случаях постулаты других религий могут использоваться определенной группой людей для регулирования социальных отношений.

Необходимо обратиться к содержанию статьи 3 Гражданского процессуального кодекса Ирана, чтобы узнать о деятельности судей Исламской Республики в связи с применением различных правил, с точки зрения использования различных нормативных правовых актов: «Судьи должны на основании закона разрешать споры, выносить постановления и решать конфликты. В случае если закон в полной мере не регулирует необходимые общественные отношения или является противоречивым, или отсутствует закон, регулирующий рассматриваемые общественные отношения, судебное решение выносится со ссылкой на надежные исламские источники (имеется в виду Коран, Сунна Пророка) или подлинные фетвы, или же на принципы права, которые не противоречат нормам шариата. Судьям запрещено по причине молчания, дефекта, неполноты или противоречивости закона отказы-

8 Гражданский кодекс Исламской Республики Иран, Минск 2020. 
ваться от вынесения решения, в противном случае, судья, отказывающийся подтверждать признанное право, будет подвергнут наказанию» 9.

\section{Заключение}

Из вышеизложенного можно сделать ряд выводов. Правовая система Ирана - это система взаимосвязанных правовых норм. Некоторые из них основаны на шиитском исламском понимании Джафара, в то время как другие имеют структуры, известные современному государству как форма республиканского правительства: выборный парламент, министры и президент. При этом преобладающие нормы основаны на религии, которая занимает лидирующее положение в законодательных источниках страны, служит для создания других правовых норм.

Правовая система Исламской Республики Иран содержит элементы мусульманско-римско-германской правовой системы. Государственные деятели Ирана используют в качестве основного источника права особый источник римско-германской системы - закон, наличие кодированного законодательства, его отраслевое деление - с религиозным содержанием, что означает, что содержание каких-либо правил не противоречит нормам ислама. Кроме того, необходимо учитывать, что в данном государстве до сих пор фетва является одним из источников права, а она является религиозноправовым явлением.

\section{Библиография}

Commentary on the Constitution of the Islamic Republic of Iran, http://www.shora-gc.ir (15.10.2020).

Fatwa of Imam Ruhollah Khomeini regarding Salman Rushdie, http://www.shora-gc.ir (15.10.2020).

A. Maini, Status of the Supreme Council of the Cultural Revolution in the legal system of Iran, //http://www.hawzah.net/fa/Article/View.

Resolution of the Supreme Council for the Cultural Revolution "On the status, goals and objectives of the Supreme Council for the Cultural Revolution", http://www.shora-gc.ir (15.10.2020).

Resolution of the Supreme Council of the Cultural Revolution "On the internal regulations of the activities of the Supreme Council of the Cultural Revolution", http://www.shora-gc. ir (15.10.2020).

9 Гражданский процессуальных кодекс Исламской Республики Иран, Тегеран 2019. 